[Manning, R. (2000). History Never Repeats Itself? Colonial Historical Trends Confront National Administration Guidelines. New Zealand Annual Review of Education, 9, 63-81]

\section{History Never Repeats Itself? Colonial Historical Trends Confront National Administration Guidelines}

\section{RICHARD MANNING}

\section{Abstract:}

This article argues that two revised National Administration Guidelines (NAG $1, v \mathcal{E} N A G 2$, iii) overlook the complexities of local histories. Although, not in any way opposing the intent of consultation implicit within the revised NAGs, in its review of the situation the article does illustrate some of the historical difficulties being faced by one school attempting to give effect to these guidelines. There may be lessons here for other similar schools. The secondary school concerned has a history of excluding Māori students and failing to effectively "consult" the local hapü (Māori subtribe/s), who have long assumed manawhenua (territorial authority) status over the area encompassing the school site. Thus any future attempt by the school to comply with the revised NAGs is likely to prove a difficult exercise.

$\mathrm{T}$ his article draws upon recent research (Manning, 1998) to illuminate some of the limitations of two revised National Administration Guidelines for schools, and argues that local histories must be thoroughly understood, and are in fact paramount in the successful implementation of such guidelines. A case study of one particular school and its impasse with a local hapu is used to illustrate this thesis.

Promulgated in The New Zealand Gazette of 25 November, 1999, the new guidelines are due to take effect from 1 July, 2000. Their text reads as follows:

\section{REVISED NAG 1}

...Each Board, through the principal and staff is required:
64 Richard Manning

(v) In consultation with the school's Māori community, to develop and make known to the school's community, policies, plans and targets for improving the achievement of Māori students...

\section{REVISED NAG 2}

Each Board of Trustees with the principal and teaching staff is required to:

(iii) Report to students and their parents on the achievement of individual students, and to the school's community on the achievement of students as a whole...including the achievement of Māori students against the plans and targets referred to in 1, (v) above.

\section{The Background}

Lauder (1987, pp. 7-8), suggested that "New Right" ideology influenced the development of New Zealand's educational policy during the "Tomorrow's Schools" era, in a manner that assumed that the education marketplace is politically neutral. My research (Manning, 1998) challenged such assumptions, using a historical methodology in one particular school. To protect the identity of the school and the communities concerned, various author and reference details were withheld, and fictitious names were created for the school, the suburb and the city in which the school is located. The name given to the school was School X, located in the suburb of "Brighton" in a city called "Willowbank". The research methodology was negotiated with the interviewees and friends/contacts from the manawhenua (local subtribe with special/treaty rights acquired through their historical occupation of the land encompassing the school site). I refer to the manawhenua as "Hapū A" and their relatives across the river as "Hapū B".

The following review article discusses some of the historical problems posed by the revised NAGs for School X, and concludes by making some more general suggestions in relation to other schools which may find themselves in a similar situation.

\section{Why Local Histories Are Still Important}

The problems confronting School X (posed by the revised NAGs) can only begin to be resolved by understanding some of the key events in the complex chain of past conflicts confronting the school administration. This article does not claim to be a definitive history. It simply argues that local historical trends have influenced School X's 
responses to Ministry of Education policy guidelines over the last two decades of the twentieth century. It seeks to explain how the Tomorrow's Schools reforms nudged the first (Pākehā-dominated) board of trustees of School X outside of its traditional cultural comfort and safety zones. Like a group of Pākehā (non-Maori, usually European) land agents 150 years before them, the board of trustees repeatedly misinterpreted Hapū A's (traditional) signals of dissent as "assent", and were often outraged by the "emotional" analyses and arguments of Hapū A representatives and students at various School Charter and/or community consultation hui (meetings).

Although former members of the board of trustees may claim to have been well-intentioned, they were largely unaware of their local colonial history, particularly the school's long history of systematically excluding Māori students. The board was poorly equipped to participate in any form of meaningful cross-cultural dialogue that might have resolved some of Hapū A's grievances.

The election of the National Party to office in 1990 led to a change in the local and national political climate that was not conducive to Hapū A's aspirations. The local Pākehā community became increasingly wary of Hapū A's efforts to establish a Māori language, "total immersion unit" within the school. Subsequently, the board of trustees lacked the widespread support of the local Pākehā community (that School X had served since its inception) that was needed to develop such a unit.

The prospect of "white flight" prompted the board of trustees to decline the establishment of a total immersion unit in accordance with Hapū A's wishes. This provoked a kaumatua (elder) from Hapū A to berate the Board for its handling of Māori education issues. The Board responded to the emotional nature of this criticism in the same manner that Pākehā land agents a century before them had responded to the emotional criticism of a "prophetic" rangatira (chief) by turning to a rival hapū (Hapū B) for support.

Thus, one of the most destructive local historical trends to resurface over the last decade has been the tendency of local Pākehā institutions (like School X) to continue to attempt to "play-off" traditional Māori political rivals against each other in consultation exercises.

This divisive legacy of nineteenth century colonisation may not be unique to the area concerned - it may well be a phenomenon that confronts Māori communities in other regions, where mainstream schools have struggled to respond appropriately to Māori aspirations. Subsequently, this article concludes that the revised NAGs possess the potential to cause other mainstream schools, either unwittingly or deliberately, to inflame local historical conflicts and grievances. It will argue that it is vital that the Crown develops proactive policies that will empower Crown entities (schools) to become more effective Treaty partners.

\section{A Brief Summary of the "Pre-European" and Early "Contact" History Relevant to the School X Site}

Willowbank is located in a river valley. The first occupants of the immediate area encompassing the School X site appear to have arrived from the "north-east". Eventually an alliance of northern iwi (a loose alliance of related but autonomous hapū) armed with muskets, invaded the valley. The rich soils of the southern end of the valley were eventually "gifted' to two hapū from one of these iwi.

School $X$ is located on land (on the eastern side of the river) in the rohe (territory) of Hapū A. Thus, Hapū A assumed manawhenua (territorial authority) status over the School X site and would expect to have this special political status recognised in any future community consultations prompted by the revised NAGs. Alternatively, Hapū B's rohe is located on the western side of the river.

\section{Talking Past Each Other: A Key Event in the Early (Local) History of Cross-cultural Dialogue}

\section{Divided responses to $P$ keh overtures}

The arrival of Pākehā land agents early in the nineteenth century provided a dilemma for the two local hapu - who were increasingly divided in their responses to the Pākehā land agents' overtures. This became obvious to the land agents during various hui held to discuss the sale of land. The land agents' translator advised them that the chief of Hapū B was the "key" person to deal with, implying that Hapū A possessed an inferior economic and political status.

My research would suggest otherwise. Hapū A was relatively powerful because it occupied pa (fortified villages) on both sides of the narrow river delta which gradually feeds into a large bay. Hapū A could have easily blocked Pākehā access to the valley's interior waterways its principal transport routes.

What motivated the translator to offer this misleading advice? He was a Pākehā trader/whaler who had "married into" Hapū B. He had a vested economic interest in meeting the needs of his "in-laws", not to 
mention his clients - the Pākehā land agents. This combination of hidden economic and political agendas established a pattern for future cross-cultural consultation exercises.

\section{Early $P$ keh misinterpretations of the "silence" of Hap A}

The accounts of various Pākehā eye-witnesses present at the final hui simplistically suggest that the rangatira opposed to the sale of land was "out-voted" by those chiefs who wanted to sell land for muskets. These observations are contentious because whether or not the land was actually "sold" or not, is still subject to debate.

What is more significant to this article is the fact that a Pākehā observer recorded patterns of "silence" that have mirrored the nature of communications between Hapū A and School X to date. The text of this observer's diary entry (Wakefield, E. J., 1845, cited in Manning, 1998 , p. 43), reads as follows:

The sixth share was assigned to [the leader of the opposition] and his followers, who took charge of the goods, and though in silence, followed the example of the others.

I suspect that the silence of the "leader" and his "followers" reflected a strong degree of disapproval for the outcome, because as Metge and Kinloch (1978, p. 21) have suggested:

Pākehā typically fail to appreciate that Māori ... handle the expression of assent and dissent in ways diametrically opposed to their own.

Expecting dissent to be verbalised they interpret silence from (Māori) as assent, only to become disillusioned when the support they thought was promised is not forthcoming. For their part, Māori ... are taken aback to find themselves allegedly committed to some project when "we didn't say anything".

Only an estimated third of those related hapu who signed the deal attended a hakari (feast) to celebrate the so-called "land-sale".

\section{Absence: A conscious form of protest?}

The translator explained to the Pākehā land agents that the absence of so many people was purely due to their need to "harvest crops". However, it was the wrong time of the season to harvest the crops concerned.

It is more likely that the absentees were "voting with their feet" as a conscious act of protest. The rangatira of Hapū A had earlier expressed strong reservations about the motives of the land agents. The rangatira's concerns were recorded by Ernst Dieffenbach (cited in Manning, 1998, p. 41), as follows:

With simple and solemn eloquence, he warned the people of the cupidity of the Europeans, pointed to the fate of the Tasmanians and Australians (Aborigines) and pictured a similar fate awaiting his own people.

The principal land agent (who had privately accused the rangatira of possessing a "bad temper") also recorded these prophecies (Wakefield, W., 1839, cited in Manning, 1998, p. 41):

He said that everyone had cleared a bit of ground and many would find themselves without anything in exchange for it... "What willyou say when the many white men come and drive you into the mountains?

Soon after the conclusion of the so-called "land-sale", the prophetic rangatira "disappeared". Eventually, his mutilated body was found amidst potato cultivations. He had gone to these cultivations to collect potatoes for the captain of a visiting ship, who was employed by the Pākehā land agents' company.

Contemporary (Pākehā) historians can only speculate on the identity of his murderer(s) but still tend to attribute much blame upon an eastern iwi, without providing any evidence to support these allegations. Would it not be plausible to suspect that his murderer(s) originated elsewhere and stood to profit from his early demise?

The death of this "prophet" created an immediate vacuum in Hapū A's leadership and a state of panic. In the midst of this crisis a large influx of Pākehā settlers was able to "swamp" Hapū A. A Native Reserves scheme (designed by the Pākehā land agents' company) soon deprived Hapū A of all their fertile lands.

Alternatively, Hapū B gained a larger area of land through the Native Reserves scheme than they had ever had before, and had no intention of allowing their relatives (Hapū A) to move onto these newly acquired lands. If local Pākehā had prospered on the lands of the late prophetic rangatira and his people, they largely had Hapū B to thank for their secure tenure.

Hapū B later joined Crown forces to fight against two northern iwi, who posed a threat to fledgling Pākehā economic and political aspirations. Why did Hapū B collaborate with the Crown? Hapū B was eager to avenge the recent deaths of close relatives at the hands of the 
northern tribes and were also anxious to preserve their access to Pākehā markets.

The eventual decline of (armed) Māori resistance in the north, accompanied by increased industrialisation, encouraged the Pākehā population of the valley to swell. Predictably, the Pākehā economy became less dependent upon Hapū B for its survival. Both of the local hapū lost most of their remaining Native Reserve lands as a consequence.

Against this backdrop, it is not surprising to find that Māori students were systematically excluded from the local secondary school (School $X)$ that was built during the mid-1920s, upon reclaimed land in a manner that had polluted both hapū's traditional fisheries.

Whilst the affluent suburb of Brighton and its new school grew and prospered, it was not until the late 1960s that anyone from Hapū A would attend the school. This student was a promising rugby player. No other students from Hapū A would enter the school until 1991. Prior to 1980, only one person from Hapū B had attended the school.

The school's demography gradually changed from 1980 onwards following the demise of a series of "gentlemen's agreements" between local principals that established School X as the "academic school" of the valley. These "gentlemen's agreements" were documented by a new, relatively liberal principal (cited in Manning, 1998, p. 63). However, it took the prospect of the Tomorrow's Schools reforms to finally nudge School $\mathrm{X}$ into an ongoing dialogue with Hapū A.

\section{Tomorrow's Schools: Local Historical Trends in Cross-Cultural} Dialogue Resurface

As early as mid-1986, this principal realised that a new policy climate would inevitably require the school to forge closer ties with Hapū A. The visiting Department of Education Inspectors were impressed with his foresight and recorded that:

It is pleasing to see ... the staff visit to the (Hapu A) marae and

increased contacts between the school and the local community.

However, the inspectors were unaware of the historical and political ramifications of this marae visit.

\section{The politics of a staff marae visit (1987)}

The visit to the marae (meeting place) of Hapū A was the first of its type in the school's sixty year history. However, many of the visitors did not enjoy their visit because of "what" a kaumatua had said to them and "how" he had said it.

The kaumatua suggested that it was "bloody cheeky" of them to suddenly appear on his doorstep (as if nothing had happened in the past), expecting a hospitable welcome. He criticised School X for having excluded the rangatahi (youth) of Hapū A from its gates for solong.

The shock experienced by the visitors was predictable. They had little knowledge of local colonial history. As Middleton (1992, p. 306) suggested:

Issues of cultural inequality and institutional racism erupted into public awareness at the very time that newly formed Boards of

Trustees assumed their administrative powers.... Many Pākehā assumed that equal rights and opportunities for Māori and Pākehā already existed.

Like the principal Pākehā land agent of the previous century (who had accused the prophetic rangatira of possessing a "bad temper"), these Pākehā visitors also failed to appreciate that a very different values system sanctioned this kaumatua's "emotive" argument. As Metge and Kinloch (pp. 28-29) have argued:

Most people disapprove of hostility and try to control it. Pākehā generally dislike open displays of hostility, requiring that individuals should at least attempt to hide their feelings under politeness .... For Māori, the marae, and for Samoans the fono, provide settings where hostility not only may but should be voiced, because the resolution of conflict is one of their major functions.... Pākehā who find themselves attacked on the marae or fono should take heart: in many ways it is the ultimate compliment, a far greater acceptance than polite platitudes.

The kaumatua's criticism was valid given the historical context and accuracy of his argument. Yet, the visitors did not "take heart", and missed an opportunity to initiate a durable reconciliation process. This incident set the trend for a series of future School Charter consultation hui, prompted by the Tomorrow's Schools reforms (1988-90).

\section{Community consultation hui: The board of trustees struggles to cope} with "emotions"

The first consultation hui held in the school library (November 7, 1989) was facilitated by the board's (Pākehā-dominated), cultural sub-committee. What should have been a significant "first" hui of its type was poorly advertised and held in a venue that was not 
"user-friendly" to local Māori. The school library was not a politically neutral venue.

The hui only occurred thanks to a series of last minute phone-calls made by various committee members. However, many of the Māori students' caregivers did not possess a telephone. Only 17 people attended this hui and (Pākehā) board of trustees' representatives comprised over half of those gathered.

The following extract from the board of trustees' minutes (Manning, p. 73), would indicate that those board of trustees members present struggled (once again) to cope with the "emotional" nature of the concerns presented to them:

One student, overcome with emotion, explained to us how racist feelings in the school (and low expectations generally) eroded any self-esteem they had had and made academic progress difficult.

The board responded to these criticisms by inviting Hapu $A$ to outline what it expected from School X. Hapū A quickly replied (Manning, p. 74), with the following recommendations:

1) A language maintenance programme;

2) An environment supporting Tikanga Māori ( Māori customs and traditions);

3) Freedom to bring in people from the community with sufficient expertise to maintain and develop bilingualism amongst the children.

Although, these demands were reasonable, given the scope for the development of Taha Māori programmes (subjects related to things Māori), the following extract from the minutes of the board's cultural sub-committee (November 1991), indicates that the board of trustees was struggling to meet Hapū A's criteria:

The meeting was informed that most subject schemes of work did acknowledge a bicultural aspect and that this is much easier in some subject areas than others.... It was decided to let this continue naturally rather than force the issue.

Did the decision of the board of trustees "not to force the issue" indicate a degree of resistance toward things Māori amongst staff? This question remains unanswered by my research (1998). Some interviewees were not so forthcoming in answering this question. Others were not employed by the school at that time and could not comment.
What is known is that three months later, board members were surprised to find that only six ex-Kohanga Reo (preschool Māori language "nest/s") students had enrolled with the school at the beginning of 1992. In some respects, this low turn-out mirrored the nature of Hapū A's boycott of the "land-sale" celebrations - 153 years earlier. The small number of Hapu A's rangatahi enrolling with the school, suggested that some of Hapū A's caregivers were already disillusioned.

To compound problems, the newly elected National Government introduced a market environment and some confusing education policy guidelines that did not help the board of trustees to resolve Hapu A's growing list of grievances.

\section{The National Government's reforms intensify a local climate of confusion and fear}

The development of National Education Guidelines (1990) formed the basis for the composition of school charters. They included specific objectives for boards of trustees that related to the provision of equity for Māori students. Ironically, the Minister of Education, (Lockwood Smith) decided that inclusion of the Treaty of Waitangi and its relevant objectives would no longer be mandatory within school charters. This sent a very contradictory message to boards of trustees.

A climate of fear also existed - largely stimulated by a mass media suspicious of Māori aspirations. During this year of transition, Hingangaroa Smith (1990, p. 187), argued that State schools (like School X) were locked into their own histories of (Pākehā) cultural reproduction and needed to comply with the demands of local Pākehā communities:

New Zealand State schools are inextricably locked into the reproduction of the dominant Pākehā culture, premised on the imperialist assumption that Pākehā-defined cultural capital is the most appropriate for all New Zealanders.

"White Flight" was one consequence of a de-zoned education marketplace and a phenomenon that the School $X$ board of trustees dreaded, because it could erode the school's funding and staffinglevels.

"White Flight" was also a symptom of the local Pākehā community's backlash against Māori aspirations, stimulated by a local media-inspired, climate of fear. "White flight" had already occurred in a local primary school with close ties to Hapu A, prompting negative publicity from the local press. The board of trustees feared that the same would happen to 
School $\mathrm{X}$ if it was considered (by the local Pākehā community) to be "turning Māori".

An anonymous research participant (Manning, p. 76), involved in the board's negotiations with Hapū A (to develop a total immersion unit), confirmed that the board suspected that Hapu A caregivers were collaborating with School X purely to achieve their own "strategic goals". These "goals" did not coincide with the "wishes" of Brighton's Pākehā community:

The Board got a bit nervous and saw it as being like a "Trojan horse"...it wasn't what the Board felt it could support, in terms of its enrolment policy or its commitment to the local area.... Some people within (Hapū A) saw the school as becoming the Māori school for the entire region, where people would be bused from everywhere...The Board would not accept that.

In a wider national context, Kelsey (1994, p. 183), suggested that the State had found itself stranded in a complex "colonial" hegemony crisis and contended that the state had consistently responded to this crisis with "pacification" strategies consisting of rhetorical concessions to Māori and/or empty promises of change.

The following comments made by the school's current principal (Manning, p. 78), suggests that the board of trustees had adopted similar "pacification" strategies to deal with a local version of the wider "colonial" crisis:

It's better to have a sort of "softly-softly" approach. Anything too radical might get some instant publicity, but in the long term, how much damage will it do?

However, the Principal quoted above later conceded (Manning, p. 90), that Hapu A did have legitimate grounds to feel disappointed with these "pacification" strategies:

I think the need for our Pākehā community is to actually know "what the hell" the Treaty of Waitangi is about...Most Pākehā people wouldn't know a land grievance if they fell over one. Like Muldoon's deficit, they just think it's some "sniveling bastard" who sold the land years ago and now wants it back...

... They're over the other side of the railroad tracks in more than one sense ... it's always been like that. (Brighton) is not a community that likes new ideas or embraces them. So, this has been a white school all of its history...For years and years they (Māori) simply weren't here, so you've got all that baggage to deal with in addressing biculturalism...Both in terms of the (Pākehā) public's perception and the perception that Māori people have of the school.

Hapū A negotiators and caregivers were unimpressed by sentiments such as those above and increasingly displayed those (traditional) signs of disapproval that the board had previously failed to detect or had chosen to ignore. The principal (Manning, p. 78), suggested that the board became increasingly frustrated with Hapu A's manner of communicating dissent:

The Board would leap through the hoop again and be somewhere and nobody would turn up except three people and a dog.

Hapū A's dissent reflected a wider (and growing) trend of Māori disillusionment with the mainstream education system. Hingangaroa Smith (1990, p. 193), observed that Māori communities had become increasingly aware of the fact that language maintenance units within mainstream schools were limited in their ability to fulfill Māori aspirations:

Māori parents have moved outside of the schooling structures not merely to exit school trends, they have also moved in a proactive way to assume greater control and autonomy over meaningful decision-making related to the education of their children.

Eventually, caregivers from Hapū A initiated the establishment of a Kura Kaupa pa (Māori-initiated alternative school, using Māorilanguage as the medium of instruction) and Hapū A's representative on School $X^{\prime}$ s board of trustees opted not to stand for re-appointment. This left the board of trustees without any Māori representation and vulnerable to criticism from the Education Review Office (ERO).

\section{The 1992 ERO "Effectiveness Review"}

School X was severely criticised by ERO in an "Effectiveness Review" (August 1992) . Some of the Report's key criticisms (cited in Manning, pp. 81-82) read as follows:

While the population of the school is strongly European it is imperative that all New Zealanders grow up, understanding that our primary commitment and identity as a nation is that of a bicultural society established under the Treaty of Waitangi. The school is not meeting its charter obligations in that:

- There is a low profile of Māori and Polynesian culture in the school. 
- Teachers of Te Reo Maori (Māori language) feel under-valued.

- Māori and Polynesian students are over-represented in the bottom quartile of academic performance. In developing policies to address the need of the lower performing students there should be a specific recognition of the needs of Māori and Polynesian students.

Although the criticisms made were valid, no tangible strategies or support were offered by ERO to help the school overcome the crisis it faced. Thus, the extract above adds credence to Thrupp's (1996, p. 65), claim that ERO reports are "politically decontextualised". This particular ERO report (1992), was oblivious to the influence of those local historical and political factors that have continued to determine the achievement levels of Māori students within School X today.

Ironically, the research of Gordon (1993, 1994), Lauder et al. (1994), Thrupp (1996) and Watson et al. (1997), suggests that it was actually the climate of competition and fear (partly stimulated by Crown agencies such as the ERO), that encouraged the "White Flight" phenomenon to flourish in the first place.

\section{An impasse is reached}

As the board's frustrations grew, a bitter exchange of words brought tensions to a climax inside the wharenui (meeting house) of Hapū A at the final School Charter consultation hui. An anonymous research participant (cited in Manning, p. 80), present at this hui alleged that:

A figure of some note from (Hapū A) arrived late, drunk, had a few

dismissive words to say and it was very counter-productive.

Clearly, an impasse had been reached. This impasse prompted the board of trustees to panic and to turn to the Chairman's professional "contacts" for help. The board's (historically naïve?) approach to Hapū A's traditional rivals (Hapū B and other rival northern hapū), had the effect of replicating the divisive strategy adopted by the Pākehā land agents when confronted by opposition from the prophetic rangatira early in the previous century.

\section{The board of trustees' divisive strategy back-fires}

The board's (Pākehā) chairman was the lawyer responsible for coordinating the Waitangi Tribunal land claims of Hapū B and other rival northern hapū from the same iwi. Hapū A had fought a (bitter) legal battle to lodge its own Treaty of Waitangi claims and to have these claims settled independently from the rest of the iwi.

The school's decision to forge closer ties with Hapū B (and rival northern hapu from the same iwi) was a direct challenge to the mana (authority) of Hapū A; who still maintain that it is their prerogative (as manawhenua) to determine the direction of Māori education policy within its territory.

Despite the existence of this intense inter-hapu rivalry, the board (1993) co-opted a rival northern hapū's (land claim) researcher as the board's Māori community representative and endorsed a request by the cultural sub-committee to have a school wharenui (meeting house) built. This Māori community representative seldom attended board meetings due to his extensive work commitments - researching a major land claim.

Subsequently, the board turned to the leader of Hapū B for advice on "naming" the school's wharenui - without consulting Hapu A. The board wanted him to give the wharenui an appropriate woman's name so as to commemorate the Centennial anniversary of the advent of Women's suffrage.

The leader of Hapū B (now-deceased) advised the school that it should name its wharenui after the mother of the eponymous ancestor of the valley's original inhabitants. The original inhabitants were the same eastern iwi still held responsible for the murder of Hapū A's prophetic rangatira, (as mentioned earlier in this article).

Clearly, the board of trustees (in its desperation to be seen to comply with the relevant National Education Guidelines) was unaware of the historical and political implications of the name "given". My sources confirm that not only does the name "rub salt" into Hapū A's "old wounds", but it also undermines the mana of the eastern iwi because it was not "given" to the school by the living descendants of the woman concerned.

Close relatives of the leader of Hapū B have suggested to me that the leader concerned "probably" collaborated with the board of trustees purely to strike a "double blow" against rival hapū and iwi interests, whilst simultaneously avenging his own hapū's long-term exclusion from the "Pākehā" school. Although we can only speculate about his motives, we can safely conclude that his decision left School X stranded not only in a local inter-hapū conflict, but a wider inter-iwi conflict. Hapū B has not played an active role in the school's decision-making processes since 1993 
To compound the problems, ERO produced an Assurance Audit (1995) and an Accountability Review (1998), that continued to highlight ERO's own limitations as an effective consumer watchdog, that is supposed to guard the interests of communities like Hapū A.

The ERO Assurance Audit (1995) complimented the school for its efforts to consult the Māori community and for the development of a wharenui. However, ERO had failed to realise that local Māori do not comprise a homogeneous community, and that the development of the wharenui was (and is) is a very contentious issue. Similarly, the ERO Accountability Review (1998) stated that:

Strategic plans have been prepared in the past year through a

consultative process involving the staff and the community.

Once again, ERO had failed to realise that local Māori are not a homogeneous community. The board of trustees had not consulted the runanga of Hapū A in this strategic planning exercise.

In relation to the ERO's false perceptions of a homogenous Māori community, this article echoes the concerns of Johnston (1997, p. 103); whose (1991) analysis of Māori participation on Auckland boards of Trustees concluded that:

Māori are always being seen as a homogenous group, and it is clear that this is not the case.

In this light, one cannot help but ask; will ERO be able to play a constructive role in monitoring School X's implementation of the revised NAGs? There are other questions, too, which must be asked.

\section{Conclusion: The Revised NAGs - Too Many Questions Left \\ Unanswered?}

This article supports Kelsey's (1994) contention that the shift of power away from the State to the private sector has dissolved the potency of the Crown to act as an effective Treaty partner. As my research (1998) suggests, the education reforms of the last decade have certainly allowed one local (Pākehā dominated) education marketplace to undermine the ability of a Crown entity (School X) to respond to the aspirations of a Māori community (Hapū A).

Subsequently, the prospect of School X attempting to implement the revised NAGs generates a need for answers to the following questions:

1) How many other (mainstream) schools share a similar history to that of School $X$ and have unintentionally (or deliberately) squandered opportunities to help resolve local Māori grievances due to fear or a lack of cultural and historical knowledge?

2) How many other mainstream schools (like School $X$ ) have unwittingly or intentionally attempted to exploit inter-tribal rivalries to comply with the conflicting demands of the Ministry of Education's policy guidelines and local (Pākehā dominated) education marketplace demands?

3) How will mainstream schools (like School X) resolve these "colonial" conflicts and or grievances and give any meaningful effect to the intent of the revised NAGs without adequate support from the Crown?

With these three questions in mind, I offer the following policy suggestions, because I believe that their implementation could help schools avoid a repetition of the sort of unproductive sequence of events experienced by School $X$ and Hapū A.

Although an in-depth discussion is limited by editorial constraints, it is my opinion that the following suggestions are entirely consistent with the principles of protection, partnership and participation, implicit within both the English and Màori texts of the Treaty of Waitangi:

- Reduce the ability of the market to undermine Māori aspirations and initiatives:

The Crown must develop proactive interventionist strategies to prevent local (Pākehā dominated) education markets from undermining Māori aspirations, as has happened in the city of Willowbank.

- Establish a Māori Education Authority to support Māori education initiatives and to guard Māori interests in the mainstream education system:

A Māori Education Authority (with statutory powers) could support the development of Māori education initiatives and simultaneously serve as a "consumer watchdog" to "guard" Māori interests in the mainstream education system. It should be remembered that 97 percent of Māori students attend "mainstream" state or state integrated schools (Ministry of Education, 1999, p. 23). There is also evidence that ERO lacks the capacity to conduct the sort of Kaupapa Māori (Māori initiated) historical and political analyses required to monitor the successful implementation of the revised NAGs. 
- Develop a series of (regional) Treaty of Waitangi education programmes: It is vital that all teachers and members of boards of trustees are aware of the cultural, historical and political contexts in which they operate locally. Regional pre-service and in-service training programmes could be developed (in partnership with hapū,iwi, the Waitangi Tribunal and Colleges of Education) that are linked to the implementation of the revised NAGs and the new Professional Standards for primary and secondary school teachers.

- Harness the potential of the mass-media to educate all New Zealanders about the work of the Waitangi Tribunal in their own localities:

For example, the Crown could resource the development of a weekly, televised documentary series (screened during prime time viewing). This series could provide regional up-dates on local claims processes, present personal interest stories and address viewers' questions, etc.

- Establish a tribunal to facilitate school-Māori community conflict resolution processes at the local level:

A tribunal with statutory powers could be developed by the Ministry of Education in partnership with the Waitangi Tribunal (and a Māori Education Authority) to review Māori grievances with local schools in the appropriate cultural, historical and political contexts. This Tribunal could facilitate mediation processes and produce binding rulings that facilitate reparation and reconciliation.

I can only conclude this article in absolute agreement with the current Principal of School X who eloquently stated that:

If a grievance is shown to be real it needs to be addressed. (Manning, p. 137)

\section{References}

Belich, J. (1987). The New Zealand wars and the Victorian interpretation of racial conflict. Auckland: Auckland University Press.

Gordon, L. (1993). Rich and poor schools in Aotearoa. Paper presented at the Annual Conference of the New Zealand Association for Research in Education, Christchurch, December.

Gordon, L. (1994). Some schools are more equal than others: Schools and market choice in Aotearoa/New Zealand. Wellington: New Zealand Council for Educational Research.
Grimstone, S. E. (1847). The Southern Settlements of New Zealand, comprising statistical information from the earliest period to the close of the year 1846. Held in Alexander Turnbull Library, Wellington.

Hingangaroa-Smith, G. (1990) Taha Māori: Pākehā capture. In J. Codd, R. Harker \&. R. Nash (Eds). Political issues in New Zealand education (2nd ed.). Palmerston North: Dunmore Press.

Jellico, R. (1930). The New Zealand Company's Native Reserves. Wellington: Government Printer.

Johnston, P. M. G. (1997). Tiptoeing through the Puha: Policy reforms for Māori Education. In M. Olssen \& K. Morris Mathews (Eds.) Education policy in New Zealand: The 1990s and beyond. Palmerston North: Dunmore Press.

Kelsey, J. (1994). Anatomy of a state in crisis. In A. Sharp (Ed.), Leap into the dark: The changing role of the New Zealand state since 1984. Auckland and Wellington: Auckland University Press and Bridget Williams Books.

Lauder, H. (1987). The New Right and educational policy in New Zealand. New Zealand Journal of Educational Studies, 22(1), 3-23.

Manning, R. F. (1998). Dial a Powhiri? A Pākehāhistorical and theoretical analysis of the Post-Colonial politics that have affected the development of a secondary school Polynesian club. Unpublished MEd thesis, Victoria University, Wellington.

Metge, J., \& Kinloch, P. (1978). "Talking past each other": Problems of cross-cultural communication. Wellington: Victoria University Press and Price Milburn.

Middleton, S. (1992, Fall). Equity, equality and biculturalism. Harvard Educational Review, 62 (3), 301-322.

Ministry of Education. (1999). New Zealand schools, Nga Kura o Aotearoa. Wellington: Ministry of Education.

Ministry of Education (1999, November 29). New Zealand Education Gazette (Official Notices) Wellington: Ministry of Education.

Ministry of Internal Affairs. (1996). Dictionary of New Zealand Biography, (DNZB), Vol. 2. Wellington: Ministry of Internal Affairs.

Lauder, H., Hughes, D., Waslander, S., Thrupp, M., McGlinn, J., Newton, S., \& Dupuis, A. (1994). The creation of market competition for education in New Zealand. (Smithfield Project). First report to the Ministry of Education. Wellington: Victoria University of Wellington. 
Thrupp, M. (1996). The Education Review Office and South Auckland schools: A case of ideology over analysis? New Zealand Annual Review of Education, 6, 51-70.

Wakefield, E. J. (1845). Adventure in New Zealand (Ed. J. Stevens). Auckland: Golden Press reprint., 1975.

Wakefield, W. (1839). Journal. Dispatches of the New Zealand Company. Wellington: National Archives.

Ward, A. (1997). National Overview (Vols. 1-3). Rangahaua Whanui Series, Waitangi Tribunal. Wellington: Government Publications.

Watson, S., Hughes, D., Lauder, H., Strathdee, D., \& Simiyu, I. (1997). Ethnicity and school choice. New Zealand Annual Review of Education, 7, 95-110.

\section{The author}

Richard Manning is a lecturer in Professional Education Studies at Te Whanau o Ako Pai ki te Upoko o te Ika (Wellington College of Education). He is currently developing his doctoral thesis in partnership with a cluster of North Island Decile One secondary schools and iwi/hapu authorities. The focus of this study will be to explore how local historical factors influence (contemporary) Māori academic achievement levels, and suggest how some historical barriers to learning might be removed. 